
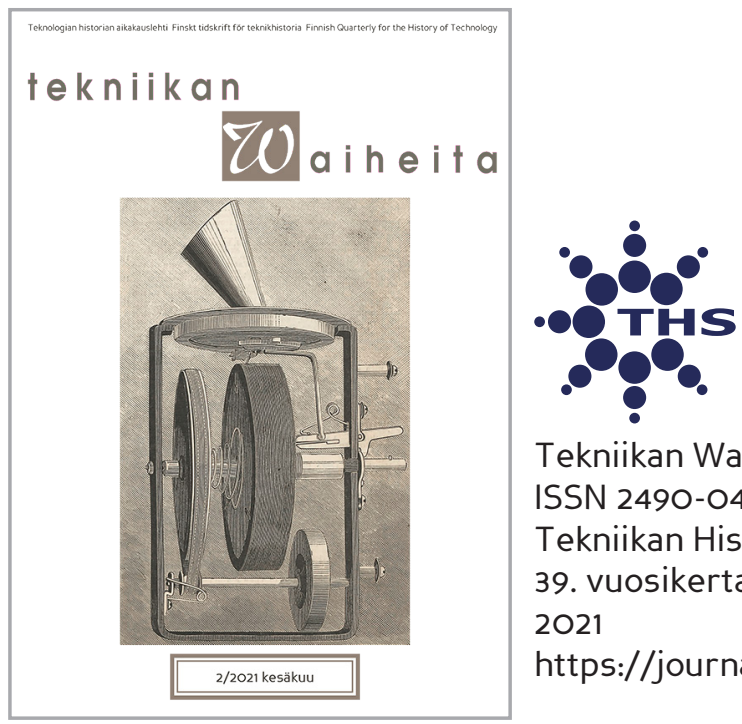

Tekniikan Waiheita

ISSN 2490-0443

Tekniikan Historian Seura ry.

39. vuosikerta: 2

2021

https://journal.fi/tekniikanwaiheita

Engineering an industrial city. 125 years of Tampere Technical Society

Petri Paju

To cite this article: Petri Paju, 'Engineering an industrial city. 125 years of Tampere Technical Society" Tekniikan Waiheita 39, no. 2 (2021): 54-62. https://doi.org/10.33355/tw.109427

To link to this article: https://doi.org/10.33355/tw.109427 


\title{
Engineering an industrial city. 125 years of Tampere Technical Society
}

\author{
Petri Paju'
}

A group of engineers and architects established a technical society in Tampere 128 years ago in 1893. In 2018, Tampere Technical Society turned 125 years. To celebrate its accomplishments and longevity, the Society published a book called Tekniikkaa hyvässä Seurassa. ${ }^{2}$ The Finnish title translates roughly 'about technology in good company'. The volume is a result of an extensive research project funded by the Society. The project aimed at studying the intertwined histories of the City of Tampere, the Society, and its members from the early 1890s until the 2010s. This article introduces the Society and summarises its historical developments in English based on the book. ${ }^{3}$

\section{Building an industrial city}

At the end of the 18th century, a town was founded by the Tammerkoski Rapids and named Tammerfors in Swedish and Tampere in Finnish. It had modest beginnings, but in the 1820s, led by foreign experts, work began to build Tampere into an industrial hub on the western edge of the Russian Empire. A few decades later, it was referred to as the "Manchester of Finland" for the first time by a Finnish public educator (Zachris Topelius) in his writings. Internationally, Tampere was one of the many growing factory cities created by industrialisation. Urban growth led to many challenges that needed to be resolved, from water supply to transport arrangements, and these tasks were taken up by engineering societies established in industrialised countries in the second half of the 19th century. ${ }^{4}$

Tampere Technical Society (TTS) was founded when eleven engineers and three architects met to discuss collaboration in Tampere on 8 March 1893. The invitation to the meeting was written by engineer Karl Snellman, the youngest son of Johan Vilhelm Snellman, who was known as the great Finnish nationalist figure of his time. Karl Snellman was in Tampere to manage the construction of the Pori railway line. The second man behind the original idea for TTS was engineer Lars E. Kjäldman, lecturer in mechanical engineering at the Tampere Industrial School (Teollisuuskoulu). The goal was to found a society that would bring together members of the Technical Association of Finland (Tekniska Föreningen i Finland) and other experts of technical fields living in Tampere. The participants of that meeting immediately started to implement the proposal. Founded in 1880, the Technical Association is the oldest still functioning engineering society in Finland, and the establishment of the Tampere club was also connected to a wider discussion on its revitalisation.

\footnotetext{
${ }^{1}$ The author worked at Chronicon Oy on the Tampere Technical Society book project. He is an adjunct professor (title of Docent) of Cultural History of Technology at the University of Turku.

${ }^{2}$ See Paju and Mauranen 2018.

${ }^{3}$ An earlier version of this article was published in Finnish in Tammerkoski magazine. See Paju $2018 \mathrm{~b}$.

Translation was done by Lingoneer Oy and paid by the Tampere Technical Society.

${ }^{4}$ For more information on the history of Tampere, see for instance Haapala and Peltola 2020.
} 


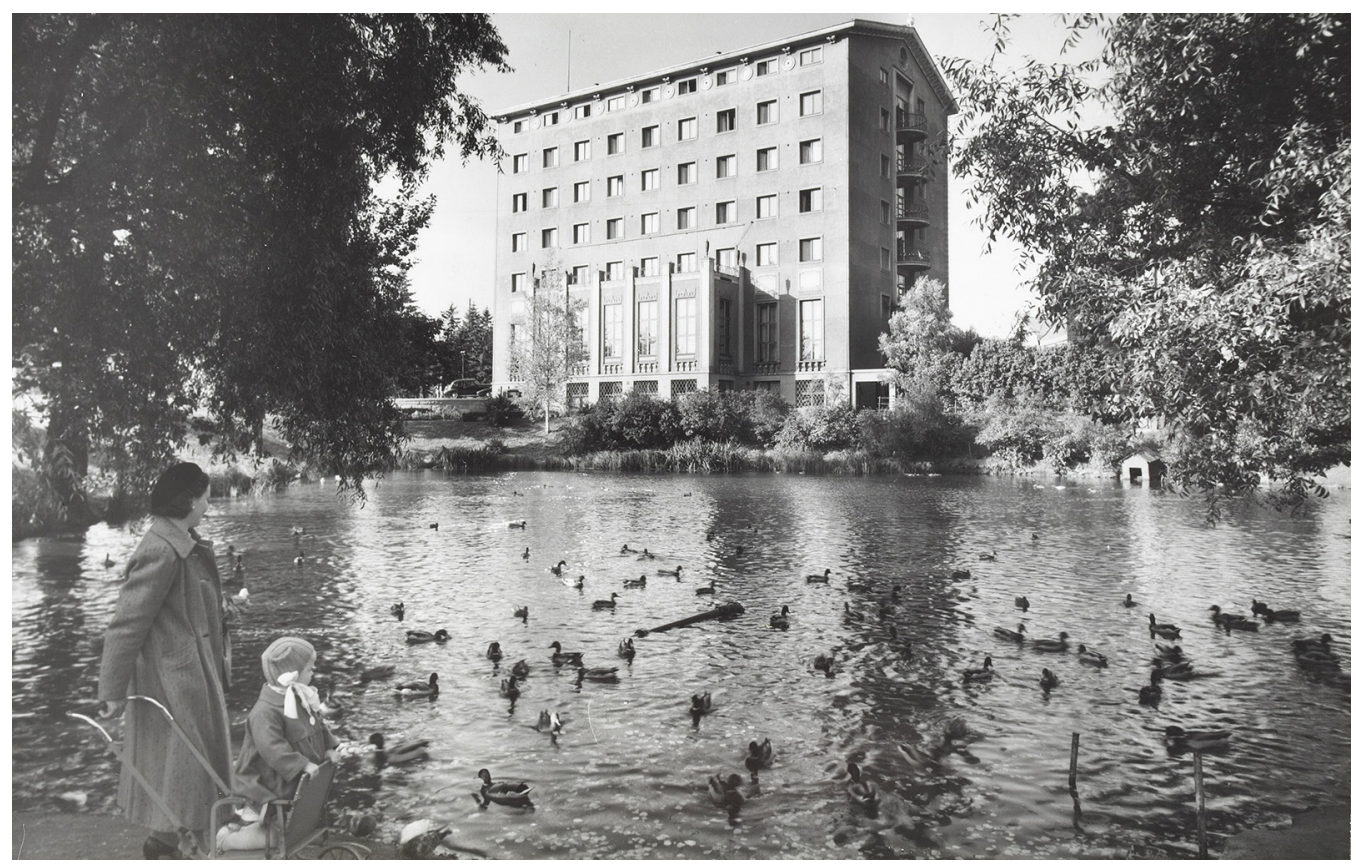

Grand Hotel Tammer was a building project of the Tampere Technical Society. The club rooms built there revolutionised the festive traditions of TTS. The building was completed in 1929. The duck pond made the place popular among children. Photograph taken in the 1930 s by Pietinen. (Museovirasto.)

The Swedish language was initially represented among the members of TTS stronger than Finnish. Swedish was the first language of many Finnish engineers and helped in communication, as TTS also hosted technical directors who had moved from Sweden and Central Europe to Tampere for work.

The activities of the Tampere Technical Club received independent features early on, although it remained a branch of the national association for a long time. Thus, the Finnishspeaking members of the local club or society, which was evolving into a separate entity, translated its name into Finnish as Tampereen Teknillinen Seura, or Tampere Technical Society, which name is still used today. TTS officially became independent in 1920.

The main activities of TTS were meetings and excursions. Members gave presentations at the meetings, and excursions were made near and far to see the latest construction projects and technical solutions. Many of the presentations dealt with solutions for the construction of Tampere or related to the development of local industry. Of the presenters, quite a few published their talks as articles in the Technical Association's magazine (Tekniska Föreningens $i$ Finland förhandlingar), whose dozens of historical bound volumes are now available digitally on the National Library website, or their talks were recorded in the minutes of TTS.

The industrial city of Tampere expanded strongly in the late 19th century. TTS started lively activities as a technical advisor to the city, being a body that brought together engineers and architects of Tampere and nearby regions. Soon, however, the membership 
base of TTS was expanded, which was an important precondition for the growth of its local significance. From the very beginning, TTS opened its doors to leading men in many fields who participated in the technical development of the city. Several pharmacists and doctors, for example, joined the society. Engineering societies worked on a wide range of development projects. Growing cities asked them for opinions, for example, on the development of the water supply network, issues that engineers and other important men in the city worked on painstakingly and on many occasions over several decades from the late 19th century long into the 20th century. TTS set up committees to give opinions to the city, and committee reports adopted at its meetings were often published in newspapers. All engineering-related reform work was brought up in TTS. For example, the proposal for a tramway in Tampere was first discussed in TTS in 1906. The investigation was led long by engineer Magnus Lavonius, who was a CEO of a cotton factory and later a very active member of T'TS.

The Russian Revolutions in 1917 caused serious problems in food supply in Finland. In anticipation of shortages, TTS expanded its activities to food production when its activists mobilised their society in collecting lichen to add to flour for baking bread. The information of the Lichen Committee of the Tampere Technical Society was distributed in newspapers nationwide. TTS feared that Tampere residents would be at risk of famine in the winter of 1918, but instead a civil war broke out in the recently independent Finland, with Tampere at centre stage. During the war, some of the large stocks of lichens collected were destroyed by pro-revolutionary labourers (Reds). When peace returned, a TTS member, engineer Eino A. Bergius, distilled liquor from the remaining lichen, reportedly mainly for industrial use.

Many associations were gentlemen's societies. Tampere Technical Society admitted the first woman, medical doctor Karolina Eskelin, in 1902, which was early compared to most other cities, but she moved to America only a year later. Architect Wivi Lönn introduced the Finnish girls' school she had designed to TTS members in 1902 but did not apply for membership. The next woman did not join TTS until 1927. Eskelin was the second woman to join any technical association in Finland - only one in Vyborg had admitted a female member before that. ${ }^{5}$

After the Technical Society, women were admitted to Tampere's Finnish Club (Tampereen Suomalainen Klubi) and Swedish Conversation Club (Konversationsklubben), later the Swedish Club of Tampere (Svenska Klubben i Tammerfors). The Tampere Trade Society (Tampereen Kauppaseura) remains all male. These associations had many members in common, and after a long break they have intensified their cooperation in the 21 st century.

Gradually since the 1920s, cities recruited more engineers to serve as civil servants and to carry out those expert tasks that were previously done on a voluntary basis. In addition to considering developments serving the common good and the public interest, associations such as TTS discussed the progress of many industries and inventions in their presentations and on excursions. In 1924, TTS organised an airborne tour of the city in which members and their wives and other lucky guests were taken on a flight over the Tammerkoski Rapids in a Finnish Air Force hydroplane. TTS strongly contributed to the relocation of the State aircraft factory to Härmälä in Tampere in the mid-1930s.

\footnotetext{
${ }^{5}$ See Paju 2018a.
} 


\section{Clubhouse Hotel Tammer and colourful festive traditions}

The Tampere Technical Society built itself a base of operations, the Grand Hotel Tammer, in the late 1920s. A hotel and restaurant started operating in the building, but new clubhouse premises that TTS had reserved for its own use soon saw the invention and establishing of new traditions. After a quiet period, the expiration of the Prohibition Act in 1932 revived and renewed the celebrations of TTS. The annual highlights of TTS came to be the Christmas party meeting in December and the annual party in February.



The TTS Christmas party in 1957 was strongly marked by the newly launched Sputnik satellites of the Soviet Union. A longer tradition was represented by Dr Carl Mäklin's (speaking) dissertation, in which the standard opponent amused members by dissecting the presentation given before. Photo possibly by Arvo Salo. (Tampere-Seura collection)

The TTS annual party has traditionally been celebrated in tailcoats and evening gowns. Time and effort were invested in the party by decorating the relevant floors of Hotel Tammer according to an annual theme. Practical arrangements were made by the Annual Party Committee, where the Women's Committee of TTS was always widely represented. The city's premier actors and other artists performed at the parties.

The party venue was decorated one year with landmarks of the metropolis of $\mathrm{New}$ York, the second in African style and the third year with religious symbols of the Far East. Tammer was in turns Venice, a magic night of the witches or, in the spirit of time, a hippie camp in 1970. In 2017, the theme of the celebration was naturally Finland 100 (years). 
Tammer and TTS were supported by many members and personalities familiar to all Tampere residents at the time, such as city architect Bertel Strömmer, who designed Hotel Tammer together with architect Georg Henriksson, and engineer Eino H. Liljeroos, who was made the first — and so far the only_ honorary chairman of TTS in 1967. At the end of the 1960s, TTS sold its share in Tammer, but the Society was allowed to stay on its premises for several years. The association still meets in the building, although in the $21 \mathrm{st}$ century the meeting grew too large to fit in its signature function room.

The story of TTS is also a story about many famous Tampere residents. Architect Bertel Strömmer chaired the Tampere Technical Society from 1940 to 1945. Many of his children continued in his footsteps. Born in 1914, Gunnar Strömmer first became interested in music and radio technology in upper secondary school. He started his career as a musician in 1933 as a drummer for Toivo Kärki's band at the Tampere restaurant Funkis. Like his father, Gunnar Strömmer was trained as an architect, and shortly after graduation he was admitted to the Technical Society. The year was 1948, and "Goony" Strömmer was asked to accompany the singing at the T'TS Christmas party. Strömmer the younger became the musical pillar of the Society. He handled the music numbers of TTS parties with such dedication that he eventually played at the TTS Christmas party 50 years in a row and continued even after that, almost until his death in 2006. Goony Strömmer, who earned a special reputation as a jazz musician, was also an important source of ideas during the organisation of the TTS annual party and as a developer of Hotel Tammer's decorations.

\section{Socially active Society in the 20005}

TTS bought stocks in the 1970s with the money from the sale of Hotel Tammer. Subsequently, it continued to invest in local companies, such as Nokia, on a long-term basis. After Nokia gained global leadership in the mobile phone market, TTS managed to sell its shareholding at peak prices at the beginning of the 21 st century. This meant that TTS had a strong financial foundation when its management started to reform its operations around 2005. Among other things, the members called for more active participation in the society at large. This request was met by organising electoral panels, i.e. by including more politics in TTS's programme in addition to technology, and the new policy has continued in the 2010s.

The membership of TTS grew steadily in the late 2000s and reached 500 people in summer 2011. It was TTS's previous record figure, first reached in the early 1980s. The continuation of busy activities in the 2010s further increased the membership year by year, so that a couple of years later in summer 2013, a new record of 600 members was reached. The growth continued from there, and in March 2017 TTS already had 700 members. Indeed, the 125-year-old TTS celebrated an unprecedented decade of membership growth.

At the same time, the membership profile of TTS has changed significantly. More and more new members were women or relatively young, or both. The active work of the section targeted at young members brought younger members than ever before to TTS. The number of women in TTS had been growing slowly since the 1930s. As recently as 1993, there were only 25 female members. The share of women in TTS exceeded $10 \%$ in the 2010-2011 season. In June 2017, TTS already had 119 female members, who made up nearly $17 \%$ of the entire membership. 


\section{Promoter of engineering education}

TTS has achieved many things. TTS assisted the ground-breaking Tampere radio in the 1920s and the launching of TV operations in Tampere in the 1950s. New engineering associations have also emerged from the sections of TTS, such as the Finnish Textile Technology Association, which was formed after the mid-1930s.

TTS built the Museum of Technology in Tampere with great perseverance. Its first industrial museum exhibition was opened in the Näsilinna building in 1926 and the Museum of Technology itself in the Frenckell boiler room in 1958. The museum, which became the property of the City of Tampere, was later given new premises on Itsenäisyydenkatu. The museum suffered a fire in December 1989, and in the 1990s the Museum of Technology was merged with the new Vapriikki Museum Centre. Through the decades, these have also presented Tampere's industrial heritage and engineering, as well as innovations made in Tampere, many of which have been made by T'TS members.

In April 2014, TTS made a visit to the repository for nuclear waste excavated in Olkiluoto in Eurajoki and to Rauma. The picture shows members walking to view Onkalo, the repository planned to last through the ages. From left, Aino Vettenranta and Antti Kiviniemi, in front Lauri Suominen, behind Pertti Halmari. On the right, Suvi Petäjäjärvi and Seppo Koskinen. (Photo: Arto Timperi/Arto Timperi collection)
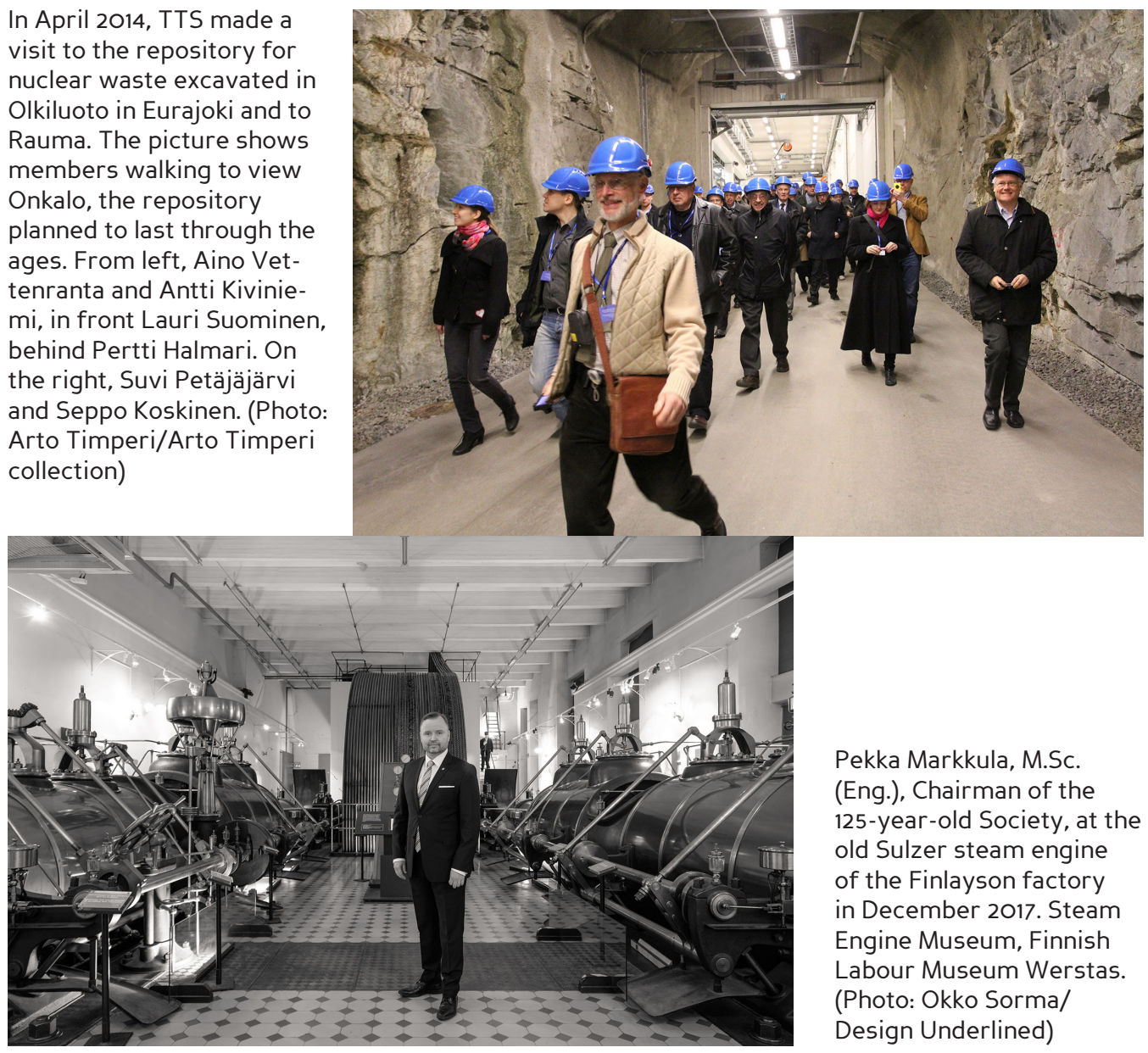

Pekka Markkula, M.Sc. (Eng.), Chairman of the 125-year-old Society, at the old Sulzer steam engine of the Finlayson factory in December 2017. Steam Engine Museum, Finnish Labour Museum Werstas. (Photo: Okko Sorma/ Design Underlined) 
The most far-reaching merits of TTS have been as a promoter of engineering education and training and higher education. The founding members of TTS included three teachers from Tampere Industrial School, and the first secretary was the rector of the said school, architect Georg Schreck. At the beginning of the 20 th century, T'TS proposed a new upper comprehensive school of technology, and this initiative led to the founding of a technical college in Tampere (Tampereen Teknillinen opisto), which was first of its kind in Finland. Subsequently, TTS supported this educational institution and the establishment of a new university of technology: Tampere University of Technology (TUT) became independent in 1972. TTS gained new active members among the professors of TUT. For example, Pekka Ahonen, the first rector of TUT, later chaired TTS. Some of the professors formed a new section in the association, which established and strengthened

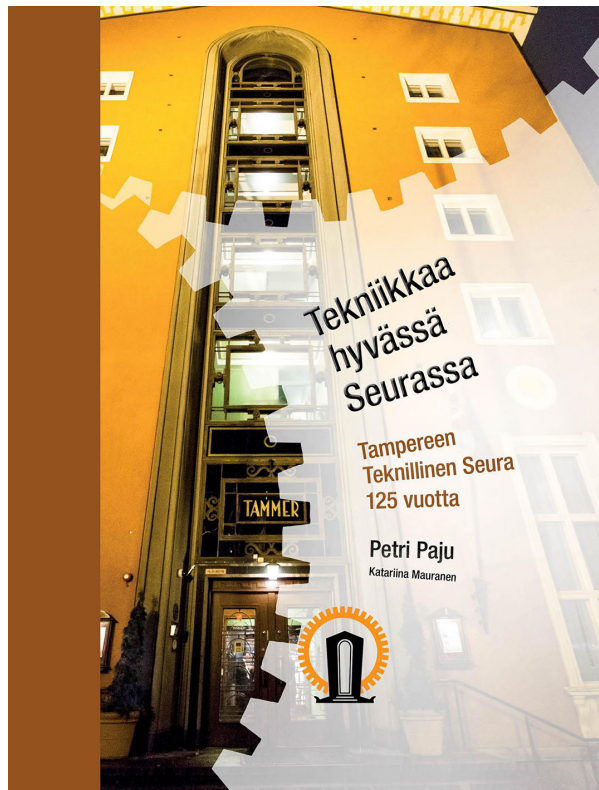

The 125-year history book of the Tampere Technical Society was published in 2018. links between the university and the industry in the Tampere region. In turn, TUT changed TTS, which began to develop more and more clearly into an association for highly educated professionals of technical fields, i.e. masters of science in engineering and architects.

At the end of the 2000s, the Tampere Technical Society was involved in donating capital to the Tampere University of Technology, which was set up in the form of a foundation. In the following decade, TTS was one of the supporters of the project that united the city's universities and other higher education institutes, as well as one of the founders of the reformed Tampere University.

The activities of Tampere Technical Society, which is now more than 125 years old, still consist of the same things as before. Most traditions began in the 1890s: regular gatherings, visits and excursions, presentations, and parties - meeting with professional colleagues and exchanging ideas about whatever is interesting at the time. Having prospered through stock sales in Nokia's heyday, TTS helps promote engineering in the Tampere region by awarding scholarships, implementing various projects, and awarding a technology entrepreneurship prize of EUR 10,000 every two years. One of the biggest projects of the anniversary year of TTS was its historical work Tekniikkaa byvässä Seurassa (Engineering in Good Company). For the first time, this project brought together the views of history researchers studying technical experts joined for the common cause of industry and technology in Tampere and the wider region over a span of 125 years. 


\section{Bibliography}

Haapala, Pertti \& Peltola, Jarmo: Global Tampere. An Economic History of the City from the 18th Century to the Present. City of Tampere, Tampere 2020.

Paju, Petri: "Ensimmäiset naiset insinöörien ja arkkitehtien yhdistyksissä." (The first women in the societies of engineers and architects, in Finnish.) Tekniikan Waiheita vol. 36, 1/2018 (a), 5-24.

Paju, Petri: "Teollisuuskaupungin ytimessä: Tampereen Teknillinen Seura 125 vuotta. (Engineering an industrial city. 125 years of Tampere Technical Society.)" Tammerkoski vol. 81, 6/2018 (b), 20-23.

Paju, Petri and Mauranen, Katariina: Tekniikkaa hyvässä Seurassa. Tampereen Teknillinen Seura 125 vuotta. Tampere Technical Society, Tampere 2018. 